\title{
PENERAPAN METODE WATERFALL PADA PERANCANGAN SISTEM INFORMASI PENGOLAHAN DATA NILAI SISWA
}

\author{
Siti Husnul Bariah ${ }^{1}$, Moch Irsad Suhanda Putra ${ }^{2}$ \\ Program Studi Pendidikan Teknologi Informasi, Fakultas Ilmu Terapan dan Sains \\ Institut Pendidikan Indonesia \\ Jl. Pahlawan No. 32 Tarogong - Garut \\ -sitihusnulbariah@institutpendidikan.ac.id \\ ${ }^{2}$ Mochirsad92@gmail.com
}

\begin{abstract}
This study aims to develop an information system of data processing of elementary school student grades by applying the waterfall method. Based on the preliminary analysis, there are several obstacles faced by class teachers in collecting student grades for one semester for the management of the final report card grades because all the assessment process documentation is still manual by handwritten and stored in a ledger so that it inhibits the management of final grades. The system development method used is the waterfall model which consists of several stages including analysis, design, coding, testing, and maintenance. Based on the results of the study it was found that the manual method was burdensome and took a long time. Information system test results conducted by the blackbox method and based on the percentage value of the results of this black box test get a percentage value of $100 \%$ valid, and testing directly by the Class Teacher with quite satisfied results
\end{abstract}

Keyword - system, information, grade, waterfall

Abstrak - Penelitian ini bertujuan untuk mengembangkan sebuah sistem informasi pengolahan data nilai siswa sekolah dasar dengan menerapkan metode waterfall. Berdasarkan analisis pendahuluan terdapat beberapa kendala yang dihadapi oleh guru kelas dalam mengumpulkan nilai-nilai siswa selama satu semester untuk pengelolaan nilai akhir raport dikarenakan semua proses dokumentasi penilaian masih manual dengan cara ditulis tangan dan disimpan pada buku besar sehingga menghambat pengelolaan nilai akhir. Metode pengembangan sistem yang digunakan yaitu model waterfall yang terdiri dari beberapa tahapan diantaranya analysis, design, coding, testing, dan maintenance. Beradsarkan hasil penelitian ditemukan bahwa dengan cara manual memberatkan dan memakan waktu cukup lama. Hasil pengujian sistem informasi yang dilakukan dengan metode blackbox dan berdasarkan nilai presentase dari hasil pengujian black box ini mendapatkan nilai Presentase sebanyak $100 \%$ valid, dan pengujian secara langsung oleh Guru Kelas dengan hasil cukup puas

Kata Kunci- sistem, informasi, nilai, waterfall

\section{PENDAHULUAN}

Pada masa sekarang, dunia mengalami proses revolusi penerapan teknologi yang disebut komputerisasi. Tentu saja bukan menjadi hal yang asing bagi kita. Saat ini komputer sudah menjadi peran penting dalam setiap pekerjaan yang berhubungan dengan pengolahan data yang mungkin dikerjakan manusia sulit namun mudah bagi komputer untuk menyelesaikannya. Sistem informasi adalah sebuah sistem informasi mengumpulkan, memproses, menyimpan, menganalisis, dan menyebarkan informasi untuk tujuan yang spesifik [1] .

Menurut Loudon dalam syukron dkk Mengemukakan bahwa Sistem Informasi (Information System) secara teknis dapat didefinisikan sebagai sekumpulan komponen yang saling berhubungan mengumpulkan atau mendapatkan, memproses, menyimpan dan mendistribusikan informasi untuk menunjang pengambilan keputusan dan pengawasan dalam suatu organisasi [2].

Menurut Wardani dalam penelitiannya sistem pengolahan data siswa menghasilkan penelitian yaitu dapat membantu menyajikan informasi pengolahan nilai yang akurat dan relevan [3]. Hasil utamanya adalah dapat menghemat waktu untuk pengolahan nilai siswa. Waktu memang sangat penting, maka dari ketiga penelitian diatas memang menitikberatkan pada waktu. Bagaimana pengolahan nilai dapat berjalan secara optimal dan efektif namun tidak membutuhkan waktu yang lama. Cukup dengan waktu yang singkat pengolahan nilai dapat dilaksanakan dengan optimal.

Perancangan sistem informasi pengolahan data nilai yang dilakukan di SMKN 1 Praya, dapat dilakukan dengan mudah, cepat, dan data yang diolah menjadi lebih akurat 
serta menjadi solusi bagi guru dalam mengolah data (Haris, dll 2018). Penggunaan sistem komputerisasi dapat mengurangi kesalahan laporan pengolahan dibandingkan dengan sistem manual yang sebelumnya diterapkan dalam perpustakaan [4].

Berdasarkah hasil observasi sementara, ditemukan beberapa aktifitas guru dalam mengolah nilai diantaranya adalah guru terlebih dahulu harus menghitung manual nilai rata-rata haruan, nilai tugas, nilai ujia yang memakan waktu hingga 2-3 jam tergantung jumlah siswa, guru memasukan nilai beberapa mata pelajaran sehingga pekerjaan seorang guru untuk mengolah nilai akhir pun semakin banyak dan berulang2. Berdasarkan penelitian terdahulu yang menyebutkan bahwa dengan adanya sebuah sistem informasi administrasi semamin membaik dan cepat. Oleh karena itu dalam penelitian ini penulis mencoba mengembangangkan sebuah sistem untuk mengolah nilainilai siswa menjadi nilai raport.

\section{TINJAUAN PUSTAKA}

\section{A. Konsep Dasar Sistem}

Sistem adalah suatu jaringan kerja dari prosedurprosedur yang saling berhubungan, berkumpul bersamasama untuk melakukan suatu kegiatan atau menyelesaikan suatu sasaran tertentu [2]. Sistem adalah Sekelompok elemen yang terintegrasi dengan maksud yang sama untuk mencapai suatu tujuan [2]. Sementara Hartono Mendefinisikan sistem adalah suatu himpunan dari berbagai bagian atau elemen, yang saling berhubungan secara terorganisasi berdasar fungsi fungsinya, menjadi satu kesatuan Dari definisi di atas dapat disimpulkan bahwa Sistem merupakan kumpulan elemen-elemen yang saling berkaitan satu sama lain dan saling bekerja sama untuk mencapai suatu tujuan dari sistem tersebut [5].

\section{B. Konsep Dasar Informasi}

Menurut Wiggins dalam Rivai dkk Sistem informasi adalah suatu sistem buatan manusia yang secara umum terdiri atas sekumpulan komponen berbasis komputer dan konvensional yang dibuat untuk menghimpun, menyimpan dan mengelola data serta menyediakan informasi keluaran kepada para pemakai [4].

Menurut Loudon dalam syukron dkk Mengemukakan bahwa Sistem Informasi (Information System) secara teknis dapat didefinisikan sebagai sekumpulan komponen yang saling berhubungan mengumpulkan atau mendapatkan, memproses, menyimpan dan mendistribusikan informasi untuk menunjang pengambilan keputusan dan pengawasan dalam suatu organisasi [2].

\section{Konsep Dasar Sistem Informasi}

Menurut Sutarman, "Sistem informasi adalah sistem yang dapat didefinisikan dengan mengumpulkan, memproses, menyimpan, menganalisis, menyebarkan informasi untuk tujuan tertentu. Seperti sistem lainnya, sebuah sistem informasi terdiri atas input (data, instruksi) dan output (laporan, kalkulasi) [6].

Infrastruktur informasi terdiri dari atas fasilitasfasilitas fisik, layanan, dan manajemen yang mendukung semua sumber daya komputer dalam suatu organisasi. Terdapat lima komponen utama dari infrastruktur informasi, yaitu sebagai berikut :

1. Hardware (perangkat keras)

2. Software (perangkat lunak)

3. Network (jaringan)

4. Database (basis data)

\section{Waterfall}

Model waterfall adalah "model klasik yang bersifat sistematis, berurutan dalam membangun software". Model ini merupakan model satu arah yang dimulai dari tahap persiapan sampai perawatan. Tahapan ini meliputi perencanaan, mendisain sistem, implementasi, verifikasi dan perawatan.

Metode waterfall merupakan metode yang sering digunakan oleh penganalisa sistem pada umumnya. Inti dari metode waterfall adalah pengerjaan dari suatu sistem dilakukan secara berurutan atau secara linear. Jadi jika langkah ke-1 belum dikerjakan, maka langkah 2 tidak dapat dikerjakan. Jika langkah ke-2 belum dikerjakan maka langkah ke-3 juga tidak dapat dikerjakan, begitu seterusnya. Secara otomatis langkah ke-3 akan bisa dilakukan jika langkah ke-1 dan ke-2 sudah dilakukan.

Fase-fase dalam Waterfall Model menurut Pressman, (2005), yaitu [7]:

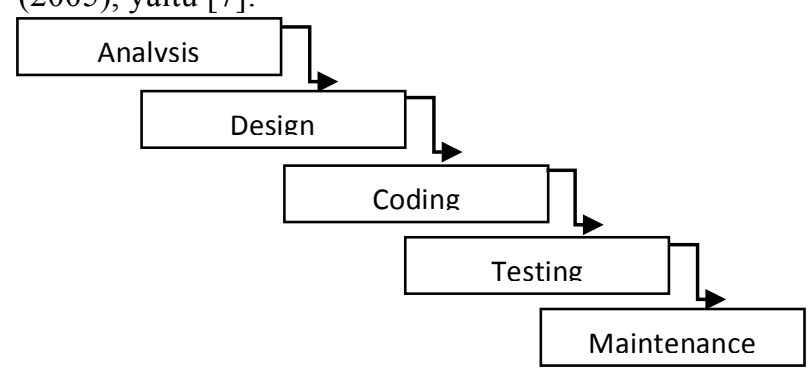

Gambar 1 Model Waterfal

\section{METODOLOGI PENELITIAN}

Metode pengembangan sistem perancangan yang digunakan peneliti dalam merancang sistem informasi pengelolaan nilai yaitu model waterfall, menurut para ahli yaitu Pressman, model waterfall adalah "model klasik yang bersifat sistematis, berurutan dalam membangun software". Model ini merupakan model satu arah yang dimulai dari tahap persiapan sampai perawatan. Tahapan ini meliputi perencanaan, mendisain sistem, implementasi, verifikasi dan perawatan [7].

Teknik pengumpulan data yang dilakukan dengan cara observasi yaitu dengan cara meneliti secara langsung proses arus informasi baik informasi masuk maupun keluar, wawancara dengan beberapa pihak sekolah supaya data yang dihasilkan lebih terjamin keakuratannya dan studi pustaka dari beberapa buku, jurnal terdahulu yang menjadi 
referensi peneliti.

\section{HASIL DAN PEMBAHASAN}

Pada sub bab ini akan dijelaskan mengenai sistem informasi penilaian siswa sedang berjalan. Analisia sistem yang sedang berjalan bertujuan untuk mengetahui lebih jelas bagaimana cara kerja sistem tersebut dan masalah yang dihadapi sistem untuk dapat dijadikan landasan usulan perancangan analisa sistem yang sedang berjalan yang dilakukan berdasarkan urutan kejadian yang ada dan dari urutan kejadian tersebut dapat dibuat Diagram Alir Dokumen (flowmap).

Sistem yang dibuat adalah sebuah sistem mengenai sistem aplikasi pengolahan nilai raport. Sistem ini dibuat untuk membantu pekerjaan guru kelas atau wali kelas yang mengelola nilai siswa mulai dari ulangan harian, ujian tengah semester dan ujian akhir semester, perhitungan nilai dan raport.

Berikut adalah beberapa masalah yang ada di dalam sistem dan penyelesaian yang penulis anjurkan.

$$
\text { TABEL I }
$$

Evaluasi Sistem yang sedang berjalan

\begin{tabular}{|c|l|l|}
\hline No & \multicolumn{1}{|c|}{ Permasalahan } & \multicolumn{1}{|c|}{ Penyelesaian } \\
\hline 1 & $\begin{array}{l}\text { Pengolahan nilai masih } \\
\text { dilakukan dalam lembaran } \\
\text { kertas sehinga proses } \\
\text { pengolahan nilai siswa } \\
\text { membutuhkan waktu yang } \\
\text { cukup lama }\end{array}$ & $\begin{array}{l}\text { Dibuatkannya sistem informasi } \\
\text { penilaian siswa yang } \\
\text { terkomputerisasi untuk } \\
\text { mempercepat proses pengolahan } \\
\text { data. }\end{array}$ \\
\hline 2 & $\begin{array}{l}\text { Belum terorganisasinya } \\
\text { data nilai sehingga } \\
\text { memungkinkan data hilang } \\
\text { dan memungkinkan } \\
\text { keamanan data kurang } \\
\text { terjamin }\end{array}$ & $\begin{array}{l}\text { Dengan adanya sistem informasi } \\
\text { penilaian siswa yang } \\
\text { terkomputerisasi maka } \\
\text { penyimpanan data disimpan di } \\
\text { dalam data base. }\end{array}$ \\
\hline 3 & $\begin{array}{l}\text { Kurang efektifnya dalam } \\
\text { proses pengolahan data } \\
\text { nilai dikarenakan sering } \\
\text { terjadinya pengulangan } \\
\text { dalam menginputkan nilai }\end{array}$ & $\begin{array}{l}\text { Dengan adanya aplikasi sistem } \\
\text { informasi pengolahan nilai siswa } \\
\text { mempermudah dan mempercepat } \\
\text { proses pengolahan data nilai }\end{array}$ \\
\hline 4 & $\begin{array}{l}\text { Penjadawalan yang } \\
\text { dilakukan masih belum } \\
\text { terkomputerisasi } \\
\text { kemungkinan terjadi } \\
\text { kesamaan jadwal } \\
\text { pelajaran. }\end{array}$ & $\begin{array}{l}\text { Dengan sistem informasi } \\
\text { akademik yang terkomputerisasi } \\
\text { maka dapat menanggulangi } \\
\text { kesamaan jadwal pelajaran }\end{array}$ \\
\hline
\end{tabular}

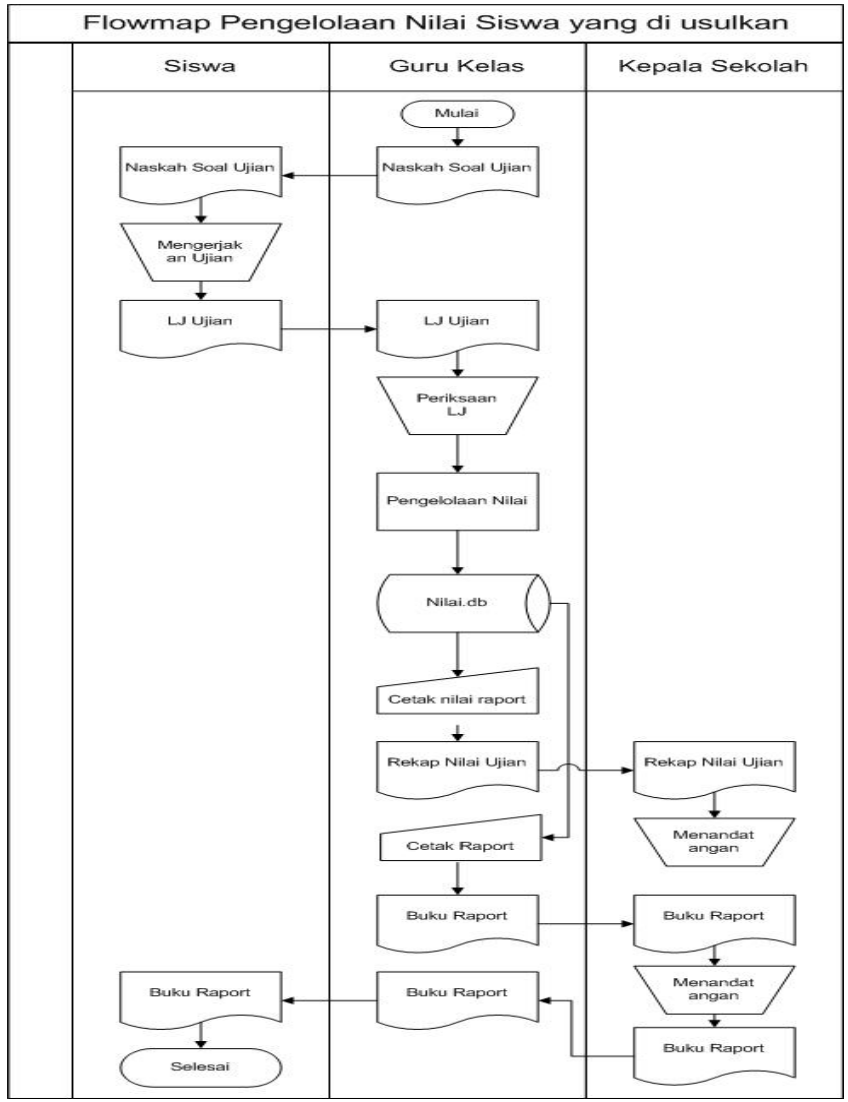

Gambar 2 Model Waterfal

\section{A. Context Diagram}

Context diagram adalah Gambaran menyeluruh prosedur kerja aplikasi pengelolaan nilai dari $D F D$. Didalam context diagram terdapat 3 (tiga) external entity, yaitu: siswa, guru kelas, dan kepala sekolah. Untuk detailnya pada Gambar dibawah ini. 


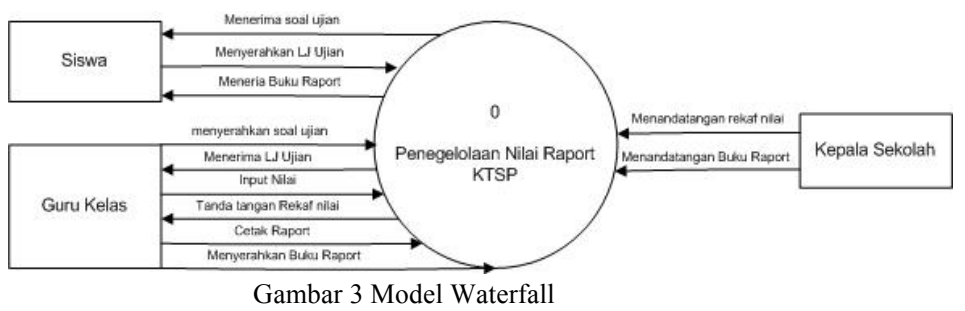

\section{Tampilan Utama}

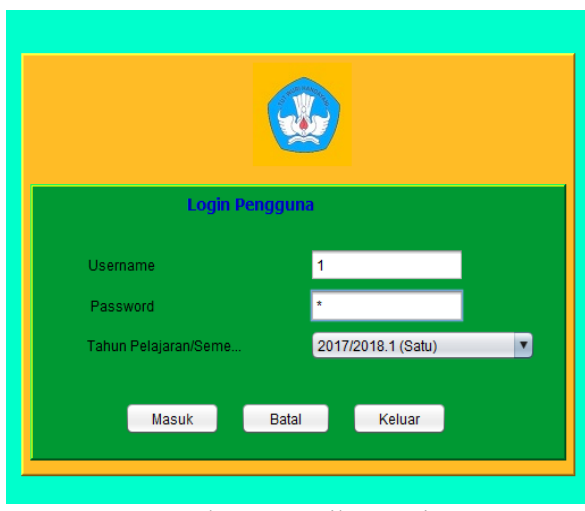

Gambar 4Tampilan Login

Gambar diatas merupakan halaman utama aplikasi, berisi form input username dan password, kemudian pilihlah tahun pelajaran/semester lalu klik masuk. Jika tidak memiliki hak akses maka tidak dapat melihat menu utama aplikasi.

\section{Tampilan Menu}

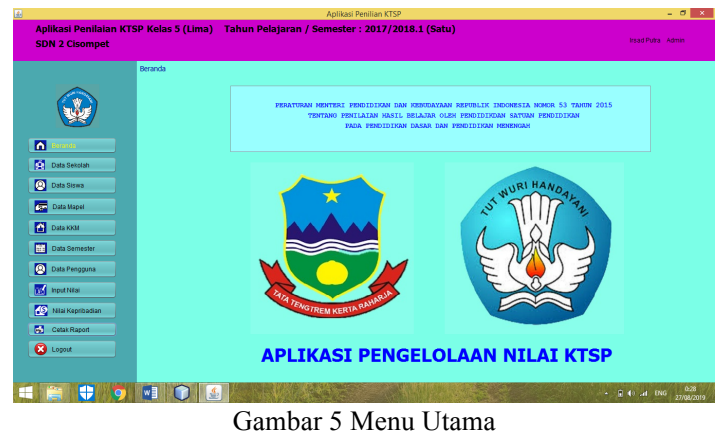

Tampilan Menu Utama terdiri dari halaman pembuka aplikasi pengelolaan nilai disertai dengan tampilan beberapa logo. Menu terdapat disebelah kiri yang dapat dipilih sesuai dengan kebutuhan.

\section{Tampilan Input Nilai}

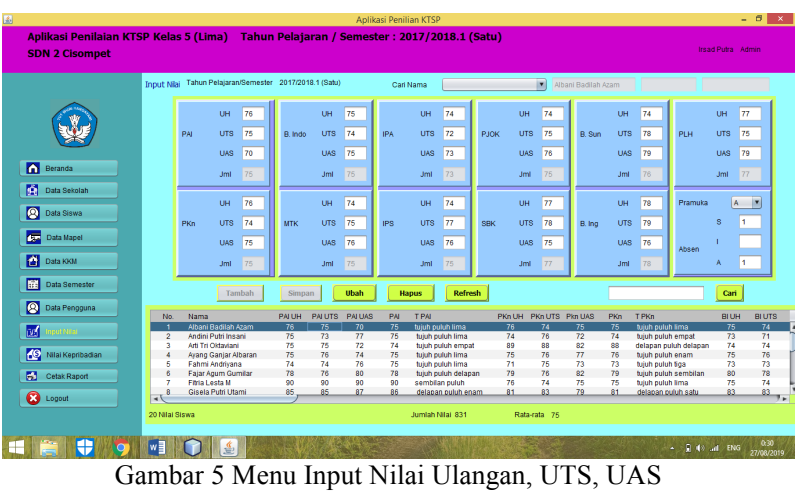

Tampilan Nilai Siswa terdapat beberapa mata pelajaran untuk di inputkan nilai diantaranya ulangan harian, UTS, dan UAS.

\section{Tampilan Cetak Nilai}

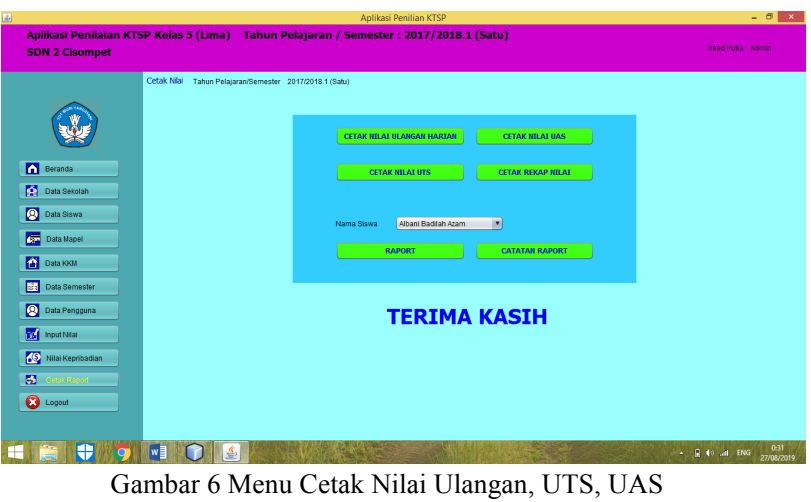

Tampilan cetak nilai terdapat beberapa cetak nilai anatara lain cetak ulangan harian, Cetak nilai UST, Cetak nilai UAS, Cetak rekaf nilai dan kemudian Cetak Raport. 


\section{Tampilan Cetak Raport}

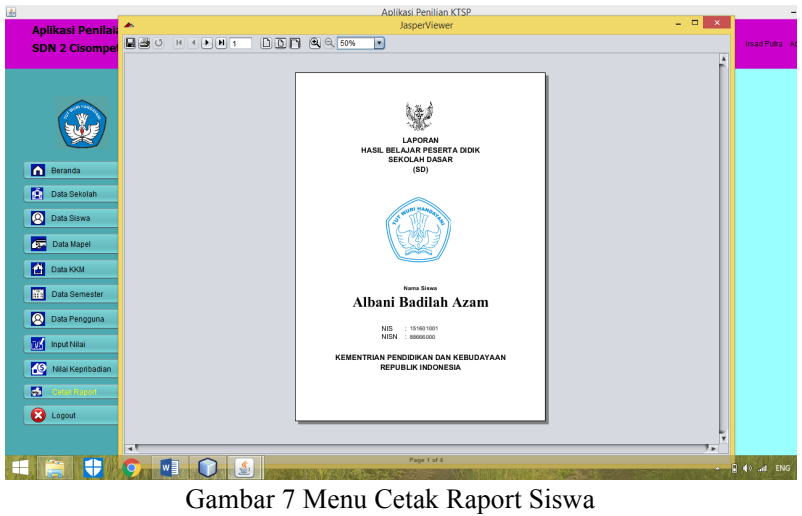

Tampilan cetak rapot adalah menu laporan akhir dari aplikasi ini, raport yang akan dicetak berdasarkan input nama siswa pada menu sebelumnya. File ini dapat langsung dicetak.

Pengujian sistem ini terdiri dar pengujian data dari user yaitu dari user Guru dan Administrator. Hasil pengujian sistem informasi yang dilakukan dengan metode black box dapat ditujukkan

Berikut ini Rekafitulasi hasil pengujian dengan blackbox dengan rincian :

a. Hasil pengujian valid diberi nilai 1 ;

b. Hasil pengujian invalid diberi nilai 0 .

TABEL II

Hasil Pengujian Login

\begin{tabular}{|c|l|l|c|}
\hline No. & \multicolumn{1}{|c|}{ Skenario Pengujian } & $\begin{array}{c}\text { Hasil } \\
\text { Pengujian }\end{array}$ & $\begin{array}{c}\text { Skor } \\
\text { Pengujian }\end{array}$ \\
\hline 1. & $\begin{array}{l}\text { Mengosongkan } \\
\text { username dan password } \\
\text { lalu klik tombol masuk. }\end{array}$ & $\begin{array}{l}\text { Sesuai } \\
\text { Harapan }\end{array}$ & 1 \\
\hline 2. & $\begin{array}{l}\text { Memasukan Username } \\
\text { atau Password salah, } \\
\text { lalu klik tombol masuk }\end{array}$ & $\begin{array}{l}\text { Sesuai } \\
\text { Harapan }\end{array}$ & 1 \\
\hline 3. & $\begin{array}{l}\text { Memasukan Username } \\
\text { atau Password benar, } \\
\text { lalu klik tombol masuk }\end{array}$ & $\begin{array}{l}\text { Sesuai } \\
\text { Harapan }\end{array}$ & 1 \\
\hline
\end{tabular}

TABEL III

Hasil Pengujian Data Siswa

\begin{tabular}{|l|l|l|c|}
\hline No. & Skenario Pengujian & Hasil Pengujian & $\begin{array}{c}\text { Skor } \\
\text { Pengujian }\end{array}$ \\
\hline 1. & $\begin{array}{l}\text { Menulis nama siswa } \\
\text { yang sudah di input } \\
\text { pada tab nama siswa, } \\
\text { lalu klik tombol } \\
\text { tambah }\end{array}$ & $\begin{array}{l}\text { Sesuai } \\
\text { Harapan }\end{array}$ & 1 \\
\hline 2. & $\begin{array}{l}\text { Mengosongkan nama } \\
\text { siswa lalu klik } \\
\text { tombol tambah Sesuai }\end{array}$ & Harapan & 1 \\
\hline 3. & $\begin{array}{l}\text { Memasukan nama } \\
\text { siswa baru yang }\end{array}$ & $\begin{array}{l}\text { Sesuai } \\
\text { Harapan }\end{array}$ & 1 \\
\hline
\end{tabular}

\begin{tabular}{|l|l|l|l|}
\hline & $\begin{array}{l}\text { belum terinputkan, } \\
\text { lalu klik tombol } \\
\text { tambah }\end{array}$ & & \\
\hline
\end{tabular}

TABEL IV

Hasil Pengujian Input Nilai Siswa

\begin{tabular}{|c|l|l|c|}
\hline No. & \multicolumn{1}{|c|}{ Skenario Pengujian } & $\begin{array}{c}\text { Hasil } \\
\text { Pengujian }\end{array}$ & $\begin{array}{c}\text { Skor } \\
\text { Pengujian }\end{array}$ \\
\hline 1. & $\begin{array}{l}\text { Menginput nilai nama } \\
\text { siswa yang sudah di input, } \\
\text { lalu klik tombol tambah. }\end{array}$ & $\begin{array}{l}\text { Sesuai } \\
\text { Harapan }\end{array}$ & 1 \\
\hline 2. & $\begin{array}{l}\text { Memilih nama siswa yang } \\
\text { belum di input tetapi nilai } \\
\text { kosong, lalu klik tombol } \\
\text { tambah. }\end{array}$ & $\begin{array}{l}\text { Sesuai } \\
\text { Harapan }\end{array}$ & 1 \\
\hline 3. & $\begin{array}{l}\text { Memilih nama siswa yang } \\
\text { belum di input nilai dan } \\
\text { mengisikan nilai, lalu klik } \\
\text { tombol tambah. }\end{array}$ & $\begin{array}{l}\text { Sesuai } \\
\text { Harapan }\end{array}$ & 1 \\
\hline
\end{tabular}

TABEL V

Hasil Pengujian Cetak Laporan

\begin{tabular}{|c|l|l|c|}
\hline No. & Skenario Pengujian & Hasil Pengujian & $\begin{array}{c}\text { Skor } \\
\text { Pengujian }\end{array}$ \\
\hline 1. & $\begin{array}{l}\text { Mencetak Nilai } \\
\text { Ulangan Harian, Klik } \\
\text { Tombol Cetak Nilai } \\
\text { Ulangan harian }\end{array}$ & $\begin{array}{l}\text { Sesuai } \\
\text { Harapan }\end{array}$ & 1 \\
\hline 2. & $\begin{array}{l}\text { Mencetak Nilai } \\
\text { Ulangan UTS, Klik } \\
\text { Tombol Cetak Nilai } \\
\text { UTS }\end{array}$ & $\begin{array}{l}\text { Sesuai } \\
\text { Harapan }\end{array}$ & 1 \\
\hline 3. & $\begin{array}{l}\text { Mencetak Nilai UAS, } \\
\text { Klik Tombol Cetak } \\
\text { Nilai UAS }\end{array}$ & $\begin{array}{l}\text { Sesuai } \\
\text { Harapan } \\
\text { Rekaf Nilai, Klik } \\
\text { Tombol Cetak Rekap } \\
\text { Nilai }\end{array}$ & $\begin{array}{l}\text { Sesuai } \\
\text { Harapan } \\
\text { Klik Tombol Raport }\end{array}$ \\
\hline 5. & $\begin{array}{l}\text { Mencetak Catatan } \\
\text { Raport, Klik Tombol } \\
\text { Catatan Raport }\end{array}$ & $\begin{array}{l}\text { Sesuai } \\
\text { Harapanan }\end{array}$ & 1 \\
\hline
\end{tabular}

Hasil rekafitulasi pengujian blackbox diatas sebagai berikut:

a. Pengujian login dari 3 jenis yang diuji mendapatkan 3 point valid dan 0 point invalid;

b. Pengujian data siswa dari 3 jenis yang diuji mendapatkan 3 point valid dan 0 point invalid;

c. Pengujian input nilai siswa dari 3 jenis yang diuji mendapatkan 3 point valid dan 0 point invalid;

d. Pengujian cetak raport dari 6 jenis yang diuji mendapatkan 6 point valid dan 0 point invalid;

e. Hasil rekafitulasi pengujian blaxkbox pada aplikasi penilaian siswa mendapatkan hasil sebagai berikut: 
Pengujian aplikasi penilain di lakukan juga langsung oleh beberapa guru kelas tentang tampilan aplikasi berikut

a. Tampilan perangkat lunak yang di gunakan sudah bagus dan menarik;

b. Perangkat lunak yang di gunakan apakah sudah membantu guru untuk penilaian siswa?;

c. Perangkat lunak yang sudah di bangun apakah memiliki penyajia informasi yang lengkap;

d. Perangkat lunak yang di bangun mempercepat penilaian siswa;

e. Perangkat lunak yang sudah di bangun mudah untuk di pelajari.

\section{DAFTAR PUSTAKA}

Turban, McClesn, Wetherbe, James, Information Technology for [1] Management Making Connections for Strategis Advantage, Inc John Wiley \& Sons, Ed., 1999, ch. 2nd.

[2] Syukron, Akhmad dan Noor Hasan, "Perancangan Sistem Informasi Rawat Jalan Berbasis Web Pada Puskesmas Winong," Jurnal Bianglala Informatika AMIK BSI Yogyakarta., vol. 3, no. 1, p. 29, 2015.

[3] Wardani, "Sistem Informasi Pengolahan Data Nilai Siswa Bebasis Web Pada Sekolah Menengah Kejuruan (SMK) PGRI 1 Pacitan," Indonesian Journal on Networking and Security, vol. 2, no. 4, 2013.

[4] Hutagalung, D.D, Aruf, "Rancang Bangun Sistem Informasi Perpustakaan Berbasis Web pada SMK Citra Negara Depok," Jurnal rekayasa informasi, vol. 7, no. 1, pp. 13-22, April 2018.

[5] Haris, Nizar, Imtihan, Ashari, "Perancangam sistem informasi pengolahan data nilai siswa," Jurnal manajemen informatika dan sistem informasi, vol. 1, no. 2, pp. 55-61, 2018.

[6] Sutarman, Buku Pengantar Teknologi Informasi. Jakarta: Bumi Aksara, 2012.

[7] Pressman, Software Engineering A Practitioner's Approach Singapore. Singapore, Mc Graw Hill Education, 2015. 